\title{
Introduction
}

\section{What Are the Conditions for Successful Refugee Return?}

\author{
Alan Simmons
}

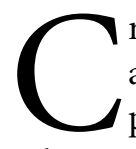

reating conditions under which refugees may safely and voluntarily return home is among the most pressing issues facing the international community. A large and rapidly growing body of literature is available on the topic. It reveals that a great deal of thought and effort has gone toward establishing the principles and procedures for successful outcomes. Yet the papers in this issue confirm that much remains to be learned and tested. Many refugee-return programs fall far short of hopes, while others succeed in certain respects only. These mixed and often disappointing findings are perhaps not surprising. In virtually all cases, efforts to organize a successful refugee return face enormous challenges.

Peaceful, voluntary refugee return depends first on correcting the persecution or ending the bloody conflict that produced the refugee flows. After general persecution and violence have ended and democracy and peace have been restored, refugee return will be faster, more complete, and more lasting if those going back to their country of citizanship can be provided with safeguards for their personal security as well as access to housing, jobs, and resources for repairing their communities. Many other supports and conditions may be necessary, if one defines success to include the eventual full participation of the returnees in national social, economic, and political life, and their active engagement in quest of solutions to national problems.

The six leading papers in this issue of Refuge present new information and emerging perspectives on the conditions required for successful refugee return. The findings are based on specific studies of efforts by international organizations, governments, and non-governmental organi- zations to establish conditions for peaceful, voluntary refugee return and resettlement. These studies focus particularly on the conditions for successful return in situations where human rights and peace have been restored sufficiently that the refugee-return projects are able to address the following specific questions: Can the returnees be guaranteed housing? Can their properties be given back to them? Will returning farmers have access to land? How will they know that any guarantees of land will be implemented? Will they have the resources and conditions to develop their own organizations and/or to participate fully in other organizations involved with solving the problems that they and the wider community face?

The collection of studies begins with a report by Bret Thiele on recent United Nations efforts to establish an international accord on the housing and property rights for returnees. This paper is followed by four in-depth examinations of how such efforts have been pursued in particular cases. Lene Madsen assesses housing and property rights among returnees to Bosnia. Paula Worby and Galit Wolfensohn, in separate papers with different specific concerns, examine access to land among Guatemalan returnees, including those who formed part of the organized return from Mexico and those who were not part of this organized return but pressed to be included in provisions of the accord covering access to land. Alison Crosby evaluates the resources and organizational "space" available to returnee women, also basing her analysis on the Guatemalan case. The leading section concludes with the examination, by K. C. Saha, of the role of the United Nations and the international community in establishing the criteria for the return of Rohingya refugees from Bangladesh to Myanmar. 
This study highlights the importance of the international community in establishing standards and supporting the return process, even in cases where the national governments involved (Myanmar and Bangladesh) have never signed the un Convention on the Status of Refugees.

These studies confirm that the most positive forces for successful refugee return are concentrated initially at the international level (largely through the United Nations) and at the local, non-governmental level. Governments responsible for implementing standards and accords therefore find themselves sandwiched between similar pressures from above and from below. This does not mean that national governments are able or willing to act fully in accord with these pressures. The following three specific problems may seriously limit their responses to progressive proposals.

First, the places to which the refugees are to return are often economically depressed and short of resources following the war, violence, and destruction. There is often a desperate lack of housing, given that much of the stock of previously existing housing has been destroyed. Returnees may find that their former properties, if they are still intact, have been taken over by others (widows, those disabled by the war, etc.) whose needs must also be addressed in any just solution. Land for farmers may have been scarce to begin with, and the lack of non-farm work may make it very difficult to accommodate the needs of local farmers (some now farming lands owned by the refugees) and the returnees. National governments in the countries to which the refugees are returning often lack the resources to address such problems.

Second, the international community generally and the United Nations specifically may be committed to a search for justice in facilitating refugee return, but they may not be prepared to provide the financial resources that would ensure that housing and employment are available for the returnees and for others whose needs must be accommodated in order to ensure justice.

Third, even when foreign governments and the national government have agreed on the provision of resources necessary for reconstruction and purchase of land in the communities to which the returnees are to locate, local and national political realities may lead to highly variable and uncertain outcomes. These outcomes include broken promises and the exclusion of some returnees from benefits that are given to others. They reflect diverse "realities" of postwar and post-repression politics. Many of the attitudes that led to conflict, violence, and repression associated with refugee flight remain imbedded in local and national political structures after peace and democracy have been officially proclaimed. The result is resistance and foot-dragging by state officials when it comes to supporting the returnees.

In sum, these studies provide new data and findings suggesting additional steps that may be taken to increase the success of refugee return programs. Following a peace accord, the international community needs to do more to ensure that resources are available for economic recovery and just solutions to housing, property, and land-access problems for both refugees and for others living in the return communities. Efforts must also be pursued to strengthen civil society organizations that are oriented to local negotiation of conflict and to local solidarity. Only in this way will a new national political agenda arise to overcome biases, injustices, and inequalities that block full success in refugee return. Arguments such as these need to be evaluated in new studies undertaken when such positive steps have been adopted. Despite much effort and some progress in refugee return programs, considerably more remains to be learned through the promotion and evaluation of programs that go beyond those that are found in the cases examined in this publication.

Alan Simmons is associate professor, Department of Sociology, York University. His current research is on Central American immigrants and refugees in Canada. 